\title{
Effects of municipal solid waste compost and fertilizers on the biomass production and yield of BRRI dhan 50
}

\author{
S Aktar, MS Islam*, MS Hossain, H Akter, S Maula, SSF Hossain ${ }^{1}$ \\ Soil Resource Development Institute, Krishi Kamar Sarak, Farmgate, Dhaka1215, Bangladesh; ${ }^{1}$ Department of \\ Agriculture Extension, Gafargaon, Mymensingh, Bangladesh
}

\begin{abstract}
An experiment was conducted at the soil science field laboratory of Bangladesh Agricultural University(BAU), Mymensingh during Boro season of 2011 to evaluate the effect of municipal waste compost (MSW) and chemical fertilizer on the biomass production and yield of boro rice(BRRI dhan50). The experimental field was silty loam in texture having $\mathrm{pH} 6.58$, organic carbon $1.0 \%$ total nitrogen $0.17 \%$, availableP11.0ppm, exchangeable $\mathrm{K}$ $0.11 \mathrm{meq} / 100 \mathrm{gm}$ soil and available sulphur $11.8 \mathrm{ppm}$. the experiment comprised of 9 treatments $\mathrm{T} 0=\mathrm{Control}$ (no fertilizer or compost), $\mathrm{T}_{1}=100 \%$ recommended fertilizer dose (N, P, K, S), $\mathrm{T}_{2}=$ Compost $5 \mathrm{t}$ ha- $1, \mathrm{~T}_{3}=$ Compost $5 \mathrm{t}$ ha- $1+100 \%$ RDF, $\mathrm{T}_{4}=$ Compost $7.5 \mathrm{t}$ ha- $1, \mathrm{~T}_{5}=$ Compost $7.5 \mathrm{t}$ ha- $1+100 \% \mathrm{RDF}, \mathrm{T}_{6}=$ Compost $10 \mathrm{t}$ ha- $1, \mathrm{~T}_{7}=$ Compost 10 t ha- $1+100 \%$ RDF, T8= Compost 20 tha-1.Compost was prepared with MSW collected from Mymensingh. Recommended dose of NPK and S at 135, 20, 50 and $10 \mathrm{~kg} / \mathrm{ha}$ respectively were applied as Urea, TSP, MOP and Gypsum. Application of MSW compost either alone or in combination of fertilizer at positive and significant effect on all the parameter studied. The plant characters like plant height, panicle length, effective tillers per hill, grain per panicle, Shoot dry weight, Root dry weight were significantly influenced by the different treatments. The highest biomass yield of $925 \mathrm{~g} / \mathrm{m}^{2}$ was recorded with the $T_{7}$ treatment and the lowest yield was noted in the T0 treatment. The same treatment i.e. $\mathrm{T}_{7}$ demonstrated the highest grain yield $(6.3 \mathrm{t} / \mathrm{ha})$ and the $\mathrm{T}_{0}$ (control) treatment had the lowest yield (3.90 t/ha). Application of MSW compost@ 10 ton/ha with 100\% RDF $\left(\mathrm{T}_{7}\right)$ also produced the highest straw yield. Lone application of MSW compost even at 20 ton/ha was not comparable with recommended dose of fertilizer in producing rice yield. Further study in needed to explore a positively to reduce fertilizer dose to the use of MSW for achieving sustainable soil fertility and crop yield.
\end{abstract}

Key words: Municipal solid waste, chemical fertilizer, yield, BRRI dhan50

Progressive Agriculturists. All rights reserved

\section{Introduction}

Rice (Oryza sativa L.) is the staple food for nearly half of the world's population. Asia accounts for about 90 percent of the production and consumption of rice with per capita consumption estimated at $104 \mathrm{~kg}$ per year, well above the global average of $65.61 \mathrm{~kg}$ (USDA, 2001 ) and provides about $70 \%$ of direct human calorie intake, making it the most important food crop in
*Corresponding Author: serajulislam344@yahoo.com

Bangladesh. Food security is the challenge in the $21^{\text {st }}$ century and most of the developing countries are facing this problem. According to the International Rice Research Institute (IRRI) report, in 2025 the demand of rice globally will be 880 million ton which is $70 \%$ more than the present production. But production is not increasing accordingly. The causes of low yield of rice 
in Bangladesh include low soil fertility, low organic matter status, conventional cultivation system, improper management and the hazards of the climatic aberration. Soil fertility deterioration has become a major constraint to higher crop production in Bangladesh. The increasing land use intensity with inadequate and unbalanced use of chemical fertilizers together with little or no use of organic manures have caused severe fertility deterioration of this country's soils resulting in stagnating or even declining of crop productivity. The organic matter status of our soils is declining due to no or low organic matter addition in soils. Since organic matter is the fundamental resource for improving soil health, hence, management of soil organic matter has now become a major issue in dealing with the problem of soil fertility and productivity in Bangladesh. Use of chemical fertilizers is an essential component of modern farming and about $50 \%$ of the world's crop production can be attributed to fertilizer use (Pradhan, 1992, Khatun et al., 2016; Islam et al., 2017a,b). Sustainable production of crops can not be maintained by using only chemical fertilizers and similarly it is not possible to obtain higher crop yield by using organic manure and intensive use of unbalanced pesticides (Islam et al., 2015; Bair, 1990). Besides, most of the farmers of this country depend on chemical fertilizer which is always an expensive input for crop production. Chemical fertilizers are likely to be even more costly in near future due to energy crisis. Use of organic manure e.g. municipal solid waste (MSW) compost along with chemical fertilizers in producing crops would be profitable and it improve soil fertility. In addition, environmental pollution can considerably be minimized by reducing the use of chemical fertilizers and increasing the use of compost. Compost is a good source of organic matter which improves soil fertility and supplies nutrients essential to plant growth. It supplies other plant essential elements such as phosphorus, potassium, calcium, sulphur and micronutrients to varying degrees. Compost is beneficial for more than its "fertilizing" capacity. It's a soil amendment and confers many physical benefits to soil. Compost improves soil structure and tilth by lowering bulk density, increasing permeability and porosity and by introducing microorganisms which produce "cementing agents" (such as gels, gums, slimes, and other polysaccharides) helpful in binding soil particles together into aggregates. When amended with compost, clayey soils are protected against compaction and sandy soils are more able to retain water and nutrients. A suitable combination of organic and inorganic source of nutrients is necessary for sustainable agriculture that can ensure food production with high quality (Reganold et al. 1990). Integrated use of organic manure and chemical fertilizer would be quite promising not only in providing greater stability in production, but also in maintaining better soil fertility (Nambiar, 1991). Thus it is necessary to find out site specific integrated use of nutrients from organic and inorganic sources for sustainable crop production. A great deal of works has been done with compost and fertilizers in many countries of the world. Information of the contribution of compost alone or in combination with chemical fertilizers to rice production is scarce in Bangladesh. Considering the above facts the present investigation was undertaken to evaluate the effects of municipal solid waste compost and fertilizers on the biomass and grain yield of BRRI dhan50

\section{Materials and Methods}

Experimental site and soil: The experiment was set up at the south west side of the Soil Science Field Laboratory of Bangladesh Agricultural University, Mymensingh during the Boro season of 2011. The soil belongs to the AEZ 9: Old Brahmaputra Floodplain. Morphological, physical and chemical characteristics of the soil are presented in the Table 1.

Rice crop: BRRI dhan50, a high yielding variety of rice was used as test crop in this experiment.

Layout of the experiment and treatments: The experiment was laid out in a Randomized Complete Block Design (RCBD) where the experimental area 
was divided into 3 blocks representing the replications to reduce soil heterogenic effects. Each block was divided into 9 unit plots with raised dykes. Thus the total number of unit plot was 27 . The unit plot size was $4.0 \mathrm{~m} \times 2.5 \mathrm{~m}$.The blocks were separated from each other by $0.5 \mathrm{~m}$ drains. Treatments were randomly distributed within the block.
$\mathrm{T}_{0}=$ Control (no fertilizer or compost), $\mathrm{T}_{1}=100 \%$ recommended fertilizer dose $\left(\mathrm{N}, \mathrm{P}, \mathrm{K} \quad \mathrm{T}_{2}=\right.$ Compost $5 \mathrm{t} \mathrm{ha}^{-1}, \mathrm{~T}_{3}=$ Compost $5 \mathrm{tha}^{-1}+10 \mathrm{v} \% \mathrm{KDF}, \mathrm{T}_{4}$ $=$ Compost $7.5 \mathrm{t} \mathrm{ha}^{-1}, \mathrm{~T}_{5}=$ Compost $7.5 \mathrm{t} \mathrm{ha}^{-1}+100 \%$ RDF, $\mathrm{T}_{6}=$ Compost $10 \mathrm{t} \mathrm{ha}^{-1}, \mathrm{~T}_{7}=$ Compost $10 \mathrm{tha}^{-1}$ $+100 \%$ RDF, $\mathrm{T}_{8}=$ Compost $20 \mathrm{tha}^{-1}$

Table 1. Characteristics of the initial soil sample

\begin{tabular}{|c|c|c|c|c|c|}
\hline \multicolumn{6}{|c|}{ Characteristics of the initial soil sample } \\
\hline \multicolumn{2}{|c|}{ Morphological characteristics } & \multicolumn{2}{|c|}{$\begin{array}{l}\text { Physiological } \\
\text { characteristics }\end{array}$} & \multicolumn{2}{|c|}{ Chemical characteristics } \\
\hline Land type & Medium high land & Sand $(\%)$ & 10.84 & pH (soil : water 1:2.5) & 6.58 \\
\hline Topography & Fairly level & Silt (\%) & 77.96 & Organic matter $(\%)$ & 1.00 \\
\hline Flood level & Above flood level & Clay $(\%)$ & 11.20 & Total nitrogen $(\%)$ & 0.17 \\
\hline Soil color & Dark grey & \multirow[t]{5}{*}{$\begin{array}{l}\text { Textural } \\
\text { class }\end{array}$} & \multirow[t]{5}{*}{ Silt loam } & Available phosphorus (ppm) & 11.0 \\
\hline Drainage & Moderately well drained & & & $\begin{array}{l}\text { Exchangeable K (me/ 100g } \\
\text { soil) }\end{array}$ & 0.11 \\
\hline Vegetation & $\begin{array}{l}\text { Rice crop grown year } \\
\text { round }\end{array}$ & & & Available sulphur (ppm) & 11.8 \\
\hline Land type & Medium high land & & & Cation exchange capacity & 11.60 \\
\hline Topography & Fairly level & & & (me/ 100g soil) & \\
\hline
\end{tabular}

Application of municipal solid waste (MSW) compost and fertilizer: Well decomposed compost was incorporated into the soil as per treatments at 7 days before transplanting of the rice seedlings. Compost was mixed thoroughly with the soil. The first dose of urea was applied at 7 days after transplanting. The remaining doses of urea were top dressed at 30 (active tillering stage) and 60 (panicle initiation stage) days after transplanting. Phosphorus, $\mathrm{K}$, and $\mathrm{S}$ were applied (a) 20, 50 and $10 \mathrm{~kg} / \mathrm{ha}$ from triple super phosphate (TSP), Muriate of potash (MOP) and gypsum, respectively, in all the plots except control as basal dose during final land preparation. Chemical composition of compost used is presented in Table 2 .

Table 2. Characteristics of municipal solid waste compost

\begin{tabular}{|l|c|c|c|}
\hline Characteristics & Value & Characteristics & Value \\
\hline Colour & Dark brown & Total P (\%) & 0.30 \\
\hline $\mathrm{pH}$ & 7.33 & Total K (\%) & 0.45 \\
\hline Organic matter (\%) & 22.5 & Total S (\%) & 0.46 \\
\hline Total N (\%) & 0.89 & C : N ratio & 14 \\
\hline
\end{tabular}


Transplanting of rice seedlings: The seedlings of BRRI dhan50 were transplanted on the $13^{\text {th }}$ February, 2011

Intercultural operations: Intercultural operations were done when necessary for ensuring and maintaining the normal growth of the crop.

Harvesting: The crop was harvested at full maturity on May 23, 2011.

\section{Procedure of recording data}

Biomass production: One hill was randomly selected from each treatment at 45 days planting to record the shoot and root biomass. Plant samples collected from the experimental plots were dried in an oven at about $65^{\circ} \mathrm{C}$ for 48 hours and then dry weight of plant samples were recorded.

Plant height: The plant height was measured from the ground level to the top of the panicle. From each plot, plants of 3 hills were measured and averaged.

Panicle length: Measurement was done from basal node of the rachis to apex of each panicle. Each observation was an average of 3 hills.

Number of effective tillers hill ${ }^{1}$ : Three hills were taken randomly from each plot and total number of tillers hill ${ }^{-1}$ was recorded. The number of effective tillers hill ${ }^{-1}$ was also recorded.

Filled grains panicle $^{-1}$ : The filled grains panicle ${ }^{-1}$ were counted and averaged.

Unfilled grains panicle $^{-1}$ : The unfilled grains panicle ${ }^{-1}$ were counted and averaged.

1000-grain weight: 1000 grains were taken from each plot and weighed in an electrical balance.

Grain and straw yields: Grain and straw yields were obtained from each plot and weighed carefully. The yields were expressed as $\mathrm{tha}^{-1}$ on $14 \%$ moisture basis.

Analysis of the initial soil: The initial soil samples were analyzed for both physical and chemical properties in the Laboratory of the Department of Soil
Science, Bangladesh Agricultural University, Mymensingh. The properties studied include particlesize analysis, $\mathrm{pH}$, organic matter content, total $\mathrm{N}$, available $\mathrm{P}$, exchangeable $\mathrm{K}$, available $\mathrm{S}$ and cation exchange capacity (CEC). The soil was analyzed following standard methods.

Particle-size analysis: The particle-size analysis was done by hydrometer method (Black, 1965)

Soil pH: The soil $\mathrm{pH}$ was measured with the help of a glass electrode $\mathrm{pH}$ meter using soil water suspension ratio of 1: 2.5 as described by Jackson (1962).

Organic carbon: Organic carbon of soil was determined by wet oxidation method described by Walkley and Black (1934).

Cation exchange capacity: Cation exchange capacity of soil was determined by sodium saturated method as outlined by Jackson (1962)..

Total nitrogen: The nitrogen of soil was estimated by micro-Kjeldahl method where soil was digested with $30 \% \mathrm{H}_{2} \mathrm{O}_{2}$, conc. $\mathrm{H}_{2} \mathrm{SO}_{4}$ and catalyst mixture of $\mathrm{K}_{2} \mathrm{SO}_{4}: \mathrm{CuSO}_{4} \cdot 5 \mathrm{H}_{2} \mathrm{O}$

Available phosphorus: Available phosphorus was extracted from the soil by measured at $600 \mathrm{~nm}$ wave length in spectrophotometric method.

Exchangeable potassium: Exchangeable potassium $(\mathrm{K})$ was determined from the soil by extraction with $1 \mathrm{~N}$ $\mathrm{NH}_{4} \mathrm{OAc}$ ( $\mathrm{pH}$ 7.0). The extracted potassium was determined by using flame photometer and calibrated with a standard K curve (Black, 1965).

Available sulphur: Available $\mathrm{S}$ content in soil was determined by turbidimetrically using $\mathrm{BaCl}_{2}$ and acid seed solution by spectrophotometer at $420 \mathrm{~nm}$.

\section{Chemical analysis of grain and straw samples}

Determination of $N, P, K$ and $S$ from plant samples:

Nitrogen: Total $\mathrm{N}$ content of plant samples was determined following micro-Kjeldahl method. After completion of digestion, $35 \% \mathrm{NaOH}$ was added with the digest for distillation. Finally the titration of 
distillate trapped in $\mathrm{H}_{3} \mathrm{BO}_{3}$ with $0.01 \mathrm{~N} \mathrm{H}_{2} \mathrm{SO}_{4}$ was done until the color changed from green to pink.

Phosphorus: Phosphorus was extracted from plant sample with $0.5 \mathrm{M} \mathrm{NaHCO}$ solution at $\mathrm{P}^{\mathrm{H}} 8.5$ following the method of Olsen et al. (1954). From 50 $\mathrm{ml}$ extract, $1 \mathrm{ml}$ digest for grain sample and $2 \mathrm{ml}$ digest for straw sample were used. The phosphorus was determined by developing blue colour by $\mathrm{SnCl}_{2}$ reduction of phosphomolybdate complex and the color intensity was measured calorimetrically at $660 \mathrm{~nm}$.

Potassium: The K was determined from the extract by using flame photometer.

Sulphur: Sulphur was determined by using $5 \mathrm{ml}$ digest (both in grain and straw). Sulphur was determined by developing turbidity by adding $1 \mathrm{ml}$ acid seed solution (20ppm $\mathrm{S}$ as $\mathrm{K}_{2} \mathrm{SO}_{4}$ in $6 \mathrm{~N} \mathrm{HCl}$ ) and $0.5 \mathrm{gm} \mathrm{BaCl}_{2}$ crystal.

Statistical analysis: The collected data were analyzed statistically using analysis of variance (ANOVA) to examine the treatment effects and the mean differences were adjudged by Duncan's Multiple Range Test (DMRT) and ranking was indicated by letters (Gomez and Gomez, 1984).

\section{Result and Discussion}

\section{Yield contributing characters}

Plant height: The plant height of BRRI dhan50 responded significantly to the application of MSW compost and fertilizers in different combinations (Table 3). The treatments $T_{1}, T_{4}, T_{5}$ and $T_{7}$ significantly increased the plant height over control. The plant height recorded in different treatments ranged from 65.56 to $74.44 \mathrm{~cm}$. The maximum plant height of 74.44 $\mathrm{cm}$ was recorded in the treatment $\mathrm{T}_{7}(100 \% \mathrm{RDF}+$ compost $\left.10 \mathrm{t} \mathrm{ha}^{-1}\right)$ which was followed by $\mathrm{T}_{5}(73.43$ $\mathrm{cm})$ and $T_{1}(72.97 \mathrm{~cm})$. The results indicated that the maximum plant height of BRRI dhan50 was observed due to the combined application of compost @ $10 \mathrm{tha}^{-1}$ with $100 \%$ NPKS fertilizers over the application of $100 \%$ NPKS as chemical fertilizers.
Panicle length: The results in Table 3 showed that panicle length of the BRRI dhan50 increased significantly due to different treatments. The panicle length due to different treatments varied from 19.38 to $22.60 \mathrm{~cm}$. The maximum panicle length $(22.60 \mathrm{~cm})$ was obtained in the treatment $\mathrm{T}_{7}$ (compost $10 \mathrm{t} \mathrm{ha}^{-1}+$ $100 \% \mathrm{RDF}$ ) which was followed by the treatment $\mathrm{T}_{1}(100 \% \mathrm{RDF})$ with the value of $21.76 \mathrm{~cm}$ which was statistically identical to the treatment $\mathrm{T}_{5}$ (compost $7.5 \mathrm{t}$ $\mathrm{ha}^{-1}+100 \% \mathrm{RDF}$ ) with the value of $21.49 \mathrm{~cm}$. The minimum panicle length $(19.38 \mathrm{~cm})$ was obtained in the control treatment $\left(\mathrm{T}_{0}\right)$ which was statistically identical to the treatment $\mathrm{T}_{6}$ (compost $10 \mathrm{t} \mathrm{ha}^{-1}$ ). Table 3 also showed that application of fertilizers in combination with compost produced longer panicle length over single application of fertilizers at the recommended dose. The results indicated that compost application with chemical fertilizer increased the panicle length to some extent.

Effective tillers hill ${ }^{1}$ : Application of compost and inorganic fertilizer statistically influenced the number of effective tillers hill ${ }^{-1}$. The number of effective tillers hill $^{-1}$ due to different treatments ranged from 8.45 to 15.33. The highest number of effective tillers hill ${ }^{-1}$ (15.33) was recorded in $T_{7}$ treatment which was statistically identical to treatments $T_{3}(14.22)$ and $T_{5}$ (14.67). The lowest value of 8.45 was noted in the $T_{0}$ treatment was statistically identical to treatments $\mathrm{T}_{1}$ (8.89), $\mathrm{T}_{2}(9.45)$ and $\mathrm{T}_{4}(9.11), \mathrm{T}_{6}(9.78)$ and $\mathrm{T}_{8}(9.80)$. Table 3 indicated that number of tillers of BRRI dhan 50 increased significantly due to the combined application of compost and fertilizers.

Filled grains panicle $e^{-1}$ : The number of filled grains panicle $^{-1}$ of BRRI dhan50 differed significantly due to application of compost and chemical fertilizers at different levels. The number of filled grains panicle $^{-1}$ due to different treatments ranged from 66.61 to 80.61 and the maximum number of grains panicle ${ }^{-1}$ of 80.61 was observed in the treatment $\mathrm{T}_{7}$ (compost @ $10 \mathrm{t} \mathrm{ha}^{-1}$ $+100 \% \mathrm{RDF})$. The minimum number of grains panicle ${ }^{-}$

${ }^{1}$ of 66.61 was recorded in the control treatment $\left(\mathrm{T}_{0}\right)$ 
which was statistically identical to the treatment $T_{1}$ (66.99). The overall result indicated that application of compost@10 t ha ${ }^{-1}$ in combination with 100\% recommended doses of fertilizers was more effective in producing more filled grains panicle ${ }^{-1}$ of BRRI dhan50. All the treatments produced higher number of filled grains panicle ${ }^{-1}$ over control.

Unfilled grains panicle ${ }^{-1}$ : Results in the Table 3 showed that the number of unfilled grains panicle ${ }^{-1}$ varied significantly due to different treatments. The number of unfilled grains panicle ${ }^{-1}$ ranged from 13.59 to 24.30 and the treatment $T_{0}$ produced the highest number of unfilled grains panicle ${ }^{-1}$ of 24.30 which was statistically identical to the treatment $T_{2}$ (23.37), $T_{4}$ (22.67) and $T_{6}(21.40)$. The treatments $T_{1}$ (15.79), $T_{3}$ (13.91), $\mathrm{T}_{5}$ (13.77) and $\mathrm{T}_{8}(15.33)$ produced statistically identical number of unfilled grains panicle ${ }^{-1}$. The lowest value for unfilled grains panicle ${ }^{-1}$ (13.59) was recorded in the treatment $T_{7}$. The results indicated that application of compost and fertilizers either singly or in combination reduces the number of unfilled grains panicle $^{-1}$.

1000-grain weight: Results presented in the Table 3 reveal that 1000-grain weight of BRRI dhan50 was influenced insignificantly due to the different treatments of MSW compost and fertilizers. The 1000grain weight ranged from 17.94 to $18.56 \mathrm{~g}$. The highest weight $(18.67 \mathrm{~g})$ of 1000 -grains was observed in $\mathrm{T}_{7}$ treatment which was statistically similar to the treatment $\mathrm{T}_{1}(18.39), \mathrm{T}_{2}(18.50), \mathrm{T}_{3}(18.11), \mathrm{T}_{4}(18.33)$, $\mathrm{T}_{5}$ (18.44), $\mathrm{T}_{6}(18.35)$ and $\mathrm{T}_{8}(18.50)$. The lowest 1000 grain weight $(17.94 \mathrm{~g})$ was observed in the control treatment $T_{0}$. The results indicated that combined or single application of compost and inorganic fertilizers showed insignificant effect on the 1000 -grain weight of rice.

Table 3. Effects of MSW compost and fertilizers on the yield contributing characters of BRRI dhan50

\begin{tabular}{|c|c|c|c|c|c|c|}
\hline Treatments & $\begin{array}{c}\text { Plant height } \\
\text { (cm) }\end{array}$ & $\begin{array}{c}\text { Panicle } \\
\text { length }(\mathrm{cm})\end{array}$ & $\begin{array}{l}\text { Effective tillers } \\
\text { hill }^{-1} \text { (No.) }\end{array}$ & $\begin{array}{l}\text { Filled grains } \\
\text { panicle }^{-1} \text { (No.) }\end{array}$ & $\begin{array}{l}\text { Unfilled grains } \\
\text { panicle }^{-1} \text { (No.) }\end{array}$ & $\begin{array}{l}\text { 1000-grain } \\
\text { weight (g) }\end{array}$ \\
\hline $\mathrm{T}_{0}$ & $65.56 \mathrm{c}$ & $19.38 \mathrm{~d}$ & $8.45 b$ & $66.61 b$ & $24.30 \mathrm{a}$ & 17.94 \\
\hline $\mathrm{T}_{1}$ & 72.97ab & $21.76 \mathrm{ab}$ & $8.89 b$ & $66.99 \mathrm{~b}$ & $15.79 \mathrm{~b}$ & 18.39 \\
\hline $\mathrm{T}_{2}$ & $67.55 \mathrm{c}$ & $19.99 \mathrm{bcd}$ & $9.45 b$ & $69.55 \mathrm{ab}$ & $23.37 \mathrm{a}$ & 18.50 \\
\hline $\mathrm{T}_{3}$ & $70.81 \mathrm{abc}$ & $20.76 \mathrm{bcd}$ & $14.22 \mathrm{a}$ & 68.84ab & $13.91 b$ & 18.11 \\
\hline $\mathrm{T}_{4}$ & $68.15 b c$ & $20.16 \mathrm{bcd}$ & $9.11 \mathrm{~b}$ & $73.50 \mathrm{ab}$ & $22.67 \mathrm{a}$ & 18.33 \\
\hline $\mathrm{T}_{5}$ & 73.43ab & $21.49 \mathrm{ab}$ & $14.67 \mathrm{a}$ & 76.33ab & $13.77 \mathrm{~b}$ & 18.44 \\
\hline $\mathrm{T}_{6}$ & $66.35 \mathrm{c}$ & $19.45 \mathrm{~d}$ & $9.78 b$ & $71.28 \mathrm{ab}$ & $21.40 \mathrm{a}$ & 18.35 \\
\hline $\mathrm{T}_{7}$ & $74.44 a$ & $22.60 \mathrm{a}$ & $15.33 \mathrm{a}$ & $80.61 \mathrm{a}$ & $13.59 \mathrm{~b}$ & 18.67 \\
\hline $\mathrm{T}_{8}$ & $66.53 c$ & $19.76 \mathrm{~cd}$ & $9.80 \mathrm{~b}$ & $75.04 \mathrm{ab}$ & $15.33 b$ & 18.50 \\
\hline CV (\%) & 1.01 & 1.12 & 5.29 & 1.83 & 5.25 & 0.50 \\
\hline LSD & 2.065 & 1.974 & 2.740 & 1.56 & 0.055 & 0.09 \\
\hline $\mathrm{SE}( \pm)$ & 0.70 & 0.23 & 0.61 & 1.32 & 0.96 & - \\
\hline
\end{tabular}

The figure (s) having common letter (s) in a column do not differ significantly at $1 \%$ level of significance, LSD = Least Significance Difference, $\mathrm{SE}( \pm)$ = Standarad Error of Means, $\mathrm{CV}(\%)=$ Coefficient of variation. 


\section{Grain and straw yields}

Grain yield: The grain yield of BRRI dhan50 was significantly influenced due to the single and combined application of compost and fertilizers (Table 4). The treatments can be ranked in order of $\mathrm{T}_{7}\left(6.32 \mathrm{t} \mathrm{ha}^{-1}\right)>$ $\mathrm{T}_{5}\left(5.75 \mathrm{tha}^{-1}\right)>\mathrm{T}_{3}\left(5.72 \mathrm{tha}^{-1}\right)>\mathrm{T}_{8}\left(5.69 \mathrm{tha}^{-1}\right)>\mathrm{T}_{6}$ $\left(4.62 \mathrm{tha}^{-1}\right)>\mathrm{T}_{1}\left(4.59 \mathrm{tha}^{-1}\right)>\mathrm{T}_{4}\left(4.50 \mathrm{tha}^{-1}\right)>\mathrm{T}_{2}(4.48$ $\left.\mathrm{t} \mathrm{ha}^{-1}\right)>\mathrm{T}_{0}\left(3.9 \mathrm{t} \mathrm{ha}^{-1}\right)$ in term of grain yields. Single application of compost @ $5 \mathrm{t} \mathrm{ha}^{-1}\left(\mathrm{~T}_{2}\right), 7.5 \mathrm{t} \mathrm{ha}^{-1}\left(\mathrm{~T}_{4}\right)$, $10 \mathrm{tha}^{-1}\left(\mathrm{~T}_{6}\right)$ and $20 \mathrm{tha}^{-1}\left(\mathrm{~T}_{8}\right)$ produced the yield of $4.48 \mathrm{t} \mathrm{ha}^{-1}, 4.50 \mathrm{t} \mathrm{ha}^{-1}, 4.62 \mathrm{t} \mathrm{ha}^{-1}$ and $5.69 \mathrm{t} \mathrm{ha}^{-1}$ which were $14.87 \%, 15.38 \%, 18.46 \%$, and $45.89 \%$ higher, respectively over control. It was observed that application of compost @ $10 \mathrm{t} \mathrm{ha}^{-1}$ with 100\% recommended doses of NPKS fertilizers performed the best in producing the grain yield of rice.

Straw yield: Application of MSW compost and fertilizers produced significantly higher straw yield of BRRI dhan50 over the control treatment. The straw yield due to the different treatments ranged from 4.90 to $9.90 \mathrm{t} \mathrm{ha}^{-1}$ with the increase of 41.02 to $102.40 \%$ over the control treatment (Table 4). The highest straw yield of $9.90 \mathrm{t} \mathrm{ha}^{-1}$ (102.04\% increases over control) was obtained in the treatment $\mathrm{T}_{7}$ (compost $10 \mathrm{t} \mathrm{ha}^{-}$ ${ }^{1}+100 \%$ recommended fertilizer dose).The lowest straw yield of $4.90 \mathrm{t} \mathrm{ha}^{-1}$ was recorded in the control treatment $\mathrm{T}_{0}$. The straw yields of rice in all the treatments were always higher to the corresponding grain yields (Table 4). Rice plants treated with fertilizers encouraged rapid vegetative growth leading to the production of higher straw yield.

Biological yield: A significant variation in biological yield of BRRI dhan50 was recorded due to the application of compost and chemical fertilizers (Table 4). The biological yield of BRRI dhan50 ranged from 8.80 to $16.62 \mathrm{t} \mathrm{ha}^{-1}$.The highest $\left(16.62 \mathrm{t} \mathrm{ha}^{-1}\right)$ and lowest $\left(8.80 \mathrm{t} \mathrm{ha}^{-1}\right)$ biological yield were recorded with the treatments $\mathrm{T}_{7}$ (compost @ $10 \mathrm{t} \mathrm{ha}^{-1}+100 \% \mathrm{RDF}$ ) and $\mathrm{T}_{0}$ (control), respectively. The biological yield of BRRI dhan50 due to different treatments ranked in order of $\mathrm{T}_{7}\left(16.22 \mathrm{tha}^{-1}\right)>\mathrm{T}_{5}\left(14.60 \mathrm{tha}^{-1}\right)>\mathrm{T}_{3}(14.20$ $\left.\mathrm{tha}^{-1}\right)>\mathrm{T}_{8}\left(13.46 \mathrm{tha}^{-1}\right)>\mathrm{T}_{6}\left(12.06 \mathrm{tha}^{-1}\right)>\mathrm{T}_{1}(11.50$ $\left.\mathrm{tha}^{-1}\right)>\mathrm{T}_{4}\left(11.46 \mathrm{tha}^{-1}\right)>\mathrm{T}_{2}\left(11.42 \mathrm{tha}^{-1}\right)>\mathrm{T}_{0}(8.80 \mathrm{t}$ $\left.\mathrm{ha}^{-1}\right)$.

Table 4. Effects of MSW compost and fertilizers on the yield of BRRI dhan50

\begin{tabular}{|c|c|c|c|c|c|}
\hline \multirow[b]{2}{*}{ Treatment } & \multicolumn{2}{|l|}{ Grain } & \multicolumn{2}{|l|}{ Straw } & \multirow{2}{*}{$\begin{array}{c}\text { Biological } \\
\text { yield }\left(\mathrm{t} \mathrm{ha}^{-1}\right)\end{array}$} \\
\hline & Yield $\left(\mathrm{t} \mathrm{ha}^{-1}\right)$ & $\begin{array}{c}\% \text { increase over } \\
\text { control }\end{array}$ & Yield* $\left(\mathrm{t} \mathrm{ha}^{-1}\right)$ & $\begin{array}{l}\text { \% increase } \\
\text { over control }\end{array}$ & \\
\hline $\mathrm{T}_{0}$ & $3.90 \mathrm{~d}$ & & $4.90 \mathrm{~d}$ & & 8.80 \\
\hline $\mathrm{T}_{1}$ & $4.59 \mathrm{c}$ & 17.69 & $6.91 \mathrm{bcd}$ & 41.02 & 11.50 \\
\hline $\mathrm{T}_{2}$ & $4.48 \mathrm{c}$ & 14.87 & $6.94 \mathrm{~cd}$ & 41.63 & 11.42 \\
\hline $\mathrm{T}_{3}$ & $5.72 b$ & 46.67 & $8.48 \mathrm{ab}$ & 73.06 & 14.20 \\
\hline $\mathrm{T}_{4}$ & $4.50 \mathrm{c}$ & 15.38 & $6.96 \mathrm{bcd}$ & 42.04 & 11.46 \\
\hline $\mathrm{T}_{5}$ & $5.75 b$ & 47.43 & $8.85 \mathrm{ab}$ & 80.61 & 14.60 \\
\hline $\mathrm{T}_{6}$ & $4.62 \mathrm{c}$ & 18.46 & $7.44 \mathrm{bc}$ & 51.84 & 12.06 \\
\hline $\mathrm{T}_{7}$ & $6.32 \mathrm{a}$ & 62.05 & $9.90 \mathrm{a}$ & 102.40 & 16.62 \\
\hline $\mathrm{T}_{8}$ & $5.69 \mathrm{~b}$ & 45.89 & $7.77 \mathrm{abc}$ & 58.57 & 13.46 \\
\hline CV (\%) & 3.08 & & 4.19 & & \\
\hline LSD & 1.326 & & 1.840 & & \\
\hline $\mathrm{SE}( \pm)$ & 0.16 & & 0.31 & & \\
\hline
\end{tabular}

*The figure(s) having common letter(s) in s column do not differ significantly at $1 \%$ level of significance 


\section{Biomass production}

Shoot weight: The shoot weight of BRRI dhan 50 increased significantly due to the application of MSW compost and fertilizers either singly or in different combinations (Table 5). All the treatments significantly increased the shoot weight over control. The shoot weight recorded in different treatments ranged from 190 to $750 \mathrm{~g} \mathrm{~m}^{-2}$. The shoot weight of BRRI dhan50 due to different treatments ranked in order of $T_{7}(750 \mathrm{~g}$ $\left.\mathrm{m}^{-2}\right)>\mathrm{T}_{5}\left(687.5 \mathrm{~g} \mathrm{~m}^{-2}\right),>\mathrm{T}_{8}\left(635 \mathrm{~g} \mathrm{~m}^{-2}\right)>\mathrm{T}_{3}(557.5 \mathrm{~g}$ $\left.\mathrm{m}^{-2}\right),>\mathrm{T}_{6}\left(550 \mathrm{~g} \mathrm{~m}^{-2}\right)>\mathrm{T}_{2}\left(510 \mathrm{~g} \mathrm{~m}^{-2}\right)>\mathrm{T}_{1}\left(305 \mathrm{~g} \mathrm{~m}^{-2}\right)$ $>\mathrm{T}_{0}\left(190 \mathrm{~g} \mathrm{~m}^{-2}\right)$. The results indicated that application of MSW compost and fertilizers either singly or in combination increased significantly the shoot weight of BRRI dhan50.

Root weight: The root weight of BRRI dhan50 increased significantly to the application of MSW compost with fertilizers in different combinations (Table 5). All the treatments significantly increased the root weight of BRRI dhan50 over control. The root weight recorded in different treatments ranged from 42.5 to $175 \mathrm{~g} \mathrm{~m}^{-2}$. Root weight of BRRI dhan50 due to different treatments ranked in order of $\mathrm{T}_{7}\left(175 \mathrm{~g} \mathrm{~m}^{-2}\right)>$ $\mathrm{T}_{6}\left(167.5 \mathrm{~g} \mathrm{~m}^{-2}\right),>\mathrm{T}_{3}\left(165 \mathrm{~g} \mathrm{~m}^{-2}\right)>\mathrm{T}_{5}\left(147 \mathrm{~g} \mathrm{~m}^{-2}\right),>\mathrm{T}_{4}$ $\left(105 \mathrm{~g} \mathrm{~m}^{-2}\right)>\mathrm{T}_{2}\left(100 \mathrm{~g} \mathrm{~m}^{-2}\right)>\mathrm{T}_{1}\left(75 \mathrm{~g} \mathrm{~m}^{-2}\right)>\mathrm{T}_{0}$ $\left(42.5 \mathrm{~g} \mathrm{~m}^{-2}\right)$. The results indicated that application of MSW compost in combination with fertilizers exerted significant increasing effect on the shoot weight of BRRI dhan50.

Total biomass production: The biomass production of BRRI dhan50 increased significantly due to the application of MSW compost with fertilizers in different combinations (Table 5). All the treatments produced significantly higher biomass over control. Total biomass production of BRRI dhan50 due to different treatments ranked in order of $\mathrm{T}_{7}\left(925 \mathrm{~g} \mathrm{~m}^{-2}\right)>$ $\mathrm{T}_{5}\left(835 \mathrm{~g} \mathrm{~m}^{-2}\right)>\mathrm{T}_{8}\left(795 \mathrm{~g} \mathrm{~m}^{-2}\right)>\mathrm{T}_{3}\left(722.5 \mathrm{~g} \mathrm{~m}^{-2}\right)>\mathrm{T}_{6}$ $\left(717.5 \mathrm{~g} \mathrm{~m}^{-2}\right)>\mathrm{T}_{2}\left(610 \mathrm{~g} \mathrm{~m}^{-2}\right)>\mathrm{T}_{4}\left(527.5 \mathrm{~g} \mathrm{~m}^{-2}\right)>\mathrm{T}_{0}$ $\left(232.5 \mathrm{~g} \mathrm{~m}^{-2}\right)$. The results indicated that application of compost and fertilizers either singly or in combination significantly increased the biomass production of BRRI dhan50.

Table 5. Effects of MSW compost and fertilizers on the biomass production of BRRI dhan50

\begin{tabular}{|c|c|c|c|c|}
\hline Treatments & $\begin{array}{c}\text { Shoot dry weight } \mathbf{( g} \\
\mathbf{m}^{-\mathbf{2}} \mathbf{)}\end{array}$ & $\begin{array}{c}\text { Root dry } \\
\text { weight }\left(\mathbf{g ~ m}^{-\mathbf{2}} \mathbf{)}\right.\end{array}$ & $\begin{array}{c}\text { Total biomass } \\
\left(\mathbf{g ~ m}^{-\mathbf{2}} \mathbf{)}\right.\end{array}$ & Shoot:Root ratio \\
\hline $\mathrm{T}_{0}$ & $190 \mathrm{f}$ & $42.5 \mathrm{c}$ & $232.5 \mathrm{f}$ & 4.47 \\
\hline $\mathrm{T}_{1}$ & $305 \mathrm{e}$ & $75 \mathrm{bc}$ & $380 \mathrm{e}$ & 4.07 \\
\hline $\mathrm{T}_{2}$ & $510 \mathrm{c}$ & $100 \mathrm{~b}$ & $610 \mathrm{~d}$ & 5.10 \\
\hline $\mathrm{T}_{3}$ & $557.5 \mathrm{c}$ & $165 \mathrm{a}$ & $722.5 \mathrm{c}$ & 3.38 \\
\hline $\mathrm{T}_{4}$ & $422.5 \mathrm{~d}$ & $105 \mathrm{~b}$ & $527.5 \mathrm{~d}$ & 4.02 \\
\hline $\mathrm{T}_{5}$ & $687.5 \mathrm{ab}$ & $147.5 \mathrm{a}$ & $835 \mathrm{ab}$ & 4.66 \\
\hline $\mathrm{T}_{6}$ & $550 \mathrm{c}$ & $167.5 \mathrm{a}$ & $717.5 \mathrm{c}$ & 3.28 \\
\hline $\mathrm{T}_{7}$ & $750 \mathrm{a}$ & $175 \mathrm{a}$ & $925 \mathrm{a}$ & 4.23 \\
\hline $\mathrm{T}_{8}$ & $635 \mathrm{~b}$ & $160 \mathrm{a}$ & $795 \mathrm{~b}$ & 3.97 \\
\hline $\mathrm{CV}(\%)$ & 6.57 & 7.21 & 6.65 & \\
\hline $\mathrm{LSD}$ & 1.343 & 1.864 & 1.488 & \\
\hline $\mathrm{SE}( \pm)$ & 1.34 & 0.36 & 1.67 & \\
\hline
\end{tabular}

The figure (s) having common letter (s) in a column do not differ significantly at $1 \%$ level of significance. 
Shoot-root ratio: Shoot: root ratio ranges from 3.28 to 5.10. The highest shoot: root ratio (5.10) was obtained in the treatment $T_{2}$. The shoot: root ratio ranked in the order of $\mathrm{T}_{2}(5.10)>\mathrm{T}_{5}(4.66)>\mathrm{T}_{0}(4.47)>\mathrm{T}_{7}(4.23)$ $>\mathrm{T}_{1}(4.07)>\mathrm{T}_{4}(4.02)>\mathrm{T}_{8}(3.97)>\mathrm{T}_{3}(3.38)>\mathrm{T}_{6}$ (3.28). The lowest shoot: root ratio (3.28) was obtained in the treatment $\mathrm{T}_{3}$.

\section{Conclusion}

It may be concluded from the study that compost application at even up to $20 \mathrm{tha}^{-1}$ was not comparable with the recommended dose of fertilizers in producing rice grain and straw yields. Application of MSW compost in combination with fertilizers had a positive effect on the yield and yield contributing characters of BRRI dhan50. Application of MSW compost @ $10 \mathrm{t}$ ha $^{-1}$ in combination with $100 \%$ of the recommended dose of NPKS fertilizers produced the maximum yield of BRRI dhan50 and the yield was considerably higher as compared to that obtained from the application of NPKS fertilizers at the recommended dose. Combined application of MSW compost and fertilizers increased biomass production as compared to that obtained from the application of NPKS fertilizers at the recommended dose. Application of MSW @ $10 \mathrm{t} \mathrm{ha}^{-1}$ with 100\% of the recommended dose of NPKS fertilizers can be practiced for the Old Brahmaputra Floodplain soils for profitable rice production.

\section{References}

Bair W (1990). Characterization of the environment for sustainable agriculture: perspectives and prospects in semi arid tropics. Indian Soc. Agron. 1: 90128.

Black CA (1965). Methods of Soil Analysis. Part I and II. American Soc. Agron. Int. Pub. Madison, Wisconsin, U.S.A

Gomez KA, Gomez AK (1984). Statistical Procedures for Agricultural Research. $2^{\text {nd }}$ edn. John Wiley and Sons. New York. : 207-215.

Islam MA, Hossain MT, Khatun M, Hossen MS (2015). Environmental impact assessment on frequency of pesticide use during vegetable production. Progressive Agriculture 26, 97-102.

Islam MA, Parvin S, Faruk MA (2017a). Impacts of riverbank erosion hazards in the Brahmaputra floodplain areas of Mymensingh in Bangladesh. Progressive Agriculture, 28(2): 73-83.

Islam MA, Akhter D, Faruk MA (2017b). Q-GIS Mapping To Explore the Status of Quality of Drinking Water in Bangladesh. IOSR Journal of Environmental Science, Toxicology and Food Technology (IOSR -JESTFT), 11(8): 17-27.

Jackson ML (1962). Soil Chemical Analysis. Prentice Hall. Inc. (Ed. Engle Wood, C.) N. J. USA.: 46.

Khatun M, Islam MA, Haque MA (2016). Studies of thunderstorms and lightning on human health, agriculture and fisheries in Mymensingh and Jamalpur district of Bangladesh. Progressive Agriculture, 27: 57-63.

Nambiar KKM (1991). Long term fertility effects on wheat productivity. Proc. Int. Conf. Maxico. DF. CIMMYT: 516-560.

Olsen SR, Cole CV, Watable FS, Dean LA (1954). Estimation of available phosphorus in soil by extraction with sodium bicarbonate U.S. Dept. Agron.Cire.P.939.

Pradhan SB (1992). Status of fertilizer use in developing countries of asia and the pacific region. Prod. Regi. FADINAP seminar, Chiang Mai, Thailand: 37-47.

Reganold JP, Robert IP, Parr JF (1990). Sustainable agriculture in the United States. An overview sustainable Agriculture: issues, perspective and prospect in semi-arid Tropics.

USDA (United State Department of Agriculture) (2001). Economic research Service Briefing Room. The economics of food, farming, natural, resources and rural America

Walkley and Black CA (1934). An examination of the Degtjarff methood for determing soil organic matter and proposed modification for the chromic acid titration method. Soil Sci . 37: 29-38. 